\title{
Effects of ultrasound support and carboxymethyl cellulose on the physicochemical properties, sensory evaluation and total microbiology of cloudy juice from soursop (Annona muricata I.)
}

\author{
Nhi Yen Thi Tran ${ }^{1,2,3, *}$, Phat Dao Tan ${ }^{1,2,3}$, Thinh Van $\mathrm{Pham}^{4}$, Truc Tran Thanh ${ }^{5,6}$, and \\ Phong Xuan Huynh",** \\ ${ }^{1}$ Institute of Environmental Technology and Sustainable Development, Nguyen Tat Thanh \\ University, Ho Chi Minh City, Vietnam \\ ${ }^{2}$ Graduate University of Science and Technology, Vietnam Academy of Science and \\ Technology, Ha Noi, Vietnam \\ ${ }^{3}$ Faculty of Environmental and Food Engineering, Nguyen Tat Thanh University, Ho Chi \\ Minh City, Vietnam \\ ${ }^{4}$ The Ho Chi Minh University of Food Industry, Ho Chi Minh City, Vietnam \\ ${ }^{5}$ College of Agriculture, Can Tho University, Can Tho City, Vietnam \\ ${ }^{6}$ School of Graduate, Can Tho University, Can Tho City, Vietnam \\ ${ }^{7}$ Biotechnology Research \& Development Institute, Can Tho University, Can Tho City, \\ Vietnam
}

\begin{abstract}
This study investigated the influence of the carboxymethyl cellulose (CMC) addition on several quality indicators of soursop juice, including $\mathrm{pH}$, dissolved solids, Lab* criteria, vitamin C, total plate count (TPC) content, microbiology, and sensory qualities. The content of CMC was allowed to vary from $0.01-0.05$ to $0.2 \%$ under sonication. The addition of $\mathrm{CMC}$ seemed to induce color changes, with total difference color (TDC) being proportionally related to CMC content. Oxidant resistance in fresh samples was $0.62 \pm 0.04 \mathrm{mg} \mathrm{GAE} / \mathrm{mL}$ and then increased at $0.05 \%$ CMC. A similar trend was also observed with the vitamin C values of the product. Visual qualities of the product were evaluated with a focus on appearance, color, and flavor with descriptive terms in a typical white liquid and odorless. Comparison with ISO quality standard indicates that the final product met with microbiological requirements.
\end{abstract}

\footnotetext{
*Corresponding author:ttynhi@ntt.edu.vn, hxphong@ctu.edu.vn
} 


\section{Introduction}

The problems of the browning process, microbiological contamination, separation of beverage products in the food industry are currently of interest. In the report, Sulaiman et al. [1], Queiroz 2008 [2], and Maricela 2000 [3] refer to the necessity of limiting damage and nutrient losses during the processing of fruits and vegetables. Cloudy juice is mentioned as a good drink for healthy nutrition. The typical source of tropical fruit is Soursop (Annona muricata L.) or "guanabana" found much in America, Australia, Africa, Asia [4]. With the abundance of nutritional potential, this fruit is used in various types of fruit juice [5], paste [6], and drying [7][8]. The remaining plant organs such as stems, leaves, and seeds are also of interest as they can be used as an antitumor activity and support health [9],[10],[11], and [12]. The edible part of this plant, bioactive compounds such as vitamin $\mathrm{C}$, total phenolic content found in the guanabana were previously published in the reports of Gruschwitz et al.,2014[13]; Moghadamtousi et al., 2015 [14]; Morais et al., 2014 [15].

The compound mentioned is susceptible to change and broken by heat, light, and environmental agents even during processing. Therefore, ultrasound in cloudy juice pasteurization is applied to limit this unwanted loss [16][17]. The objective of thermal treatment assisted microwave treatment was to inactivate the polyphenol oxidase, which comprised $\mathrm{Cu}^{2+}$ ions and caused color deteriorations during processing. Besides, microwave treatment was found to possibly homogenize CMC in the mixture as well as contribute to the pasteurization process of the mixture solution [17].

Referred to as essential support in the stable suspensions system - Carboxymethyl cellulose is the agent that prolongs the suspended phenomenon of insoluble solids in solution [18]. Previous experiments in fruit juice verified the contribution of CMC as a particle retention agent in the water, changing the rheology and nutrition of the sample [19][20].

This study aimed to analyse the effect of $\mathrm{CMC}$ concentration on $\mathrm{pH}$ parameters, soluble solids content, TAA, TPC, Lab* of soursop's cloudy juice. In particular, the process of a homogeneous suspended system is supported by ultrasound to save time and limit the loss of components in the product.

\section{Methods and materials}

Cloudy juices of $12^{\circ}$ Brix (fresh samples) were obtained at the laboratory by crushing and pressing the mash through a mesh $1 \mathrm{~mm}$ sieve. Samples obtained were then added with sodium carboxymethyl cellulose $(\mathrm{MW}=771,000)$ from China (distributed by Van An company, Vietnam). Gums (solid basis - the range 0.01-0.05$0.1-0.15-0.2 \%$.) were added to cloudy juices and stirred with continuous support from sound wave equipment (3L GT SONIC Ultrasonic Cleaner with Heater GT1730QTS) (settings of $70^{\circ} \mathrm{C}, 15$ minutes, constant frequency of $40 \mathrm{kHz}$ ) [21]. 


\subsection{Determination of soluble solids content, $\mathrm{pH}$ value, and total color difference (TCD)}

A Model TI-RBX0010A refractometer was used to measure soluble solids content in nectar samples. The sample was dropped onto the measuring glass and recorded the results. Display measurements were calculated based on unit ${ }^{\circ}$ Brix. Usually, this parameter is accepted at $8-15^{\circ}$ Brix for commercial products.

The $\mathrm{pH}$ value of the cloudy juice was a measurement of the Consort multiparameter analyzer in $250 \mathrm{~mL}$ solution. The $\mathrm{pH}$ of $\mathrm{CMC}$ blended nectar samples was determined before and after homogenization with ultrasound support

The dark light color difference coefficient was done according to Torres et al. [22]. Lightness the $\left(\mathrm{L}^{*}\right), \mathrm{a}^{*}$, and $\mathrm{b}^{*}$ range indicate a wide (lightness-darknessredness-greenness-blueness-yellowness). The number of measurements available repeated triplicates at random locations of the sample. Total color difference (TD) available determined following Eq. (1) [22]:

$$
C D=\sqrt{\left(L-L^{\circ}\right)^{2}+\left(a-a^{\circ}\right)^{2}+\left(b-b^{\circ}\right)^{2}}
$$

\subsection{Determination of Total phenolic content}

The 6 × $50 \mathrm{~mL}$ sample was centrifuged using a Benchtop High-Speed Centrifuge (LACE16 model) with $6000 \mathrm{rpm}$ speed within 15 minutes. The solution is then filtered through Whatman No.1 paper. Then, $500 \mu \mathrm{l}$ of Folin-Ciocalteu reagent were mixed with $100 \mu \mathrm{l}$ diluted sample (ratio 1:4), $400 \mu$ l of $\mathrm{Na}_{2} \mathrm{CO}_{3} 7.5 \%$ (w/v). The method for determining TPC was adjusted by Silva et al. [23]. Absorbance at 760nm was measured after one $\mathrm{h}$, using a spectrophotometer. Results were expressed as grams of gallic acid equivalents per $\mathrm{mL}$ of sample $(\mathrm{mg} \mathrm{GAE} / \mathrm{mL})$.

\subsection{Sensory evaluation}

A survey was conducted on 30 people. Evaluation table for samples with different CMC concentrations $(0.01-0.05-0.1-0.15-0.2)$. The tester receives the coded sample and scores according to the TCVN 3215 - 79 test.

\subsection{Statistical analysis}

Data were analysed by using SPSS 15.0 software. Variance analysis (ANOVA) of triplicate experiment was applied to determine the differences between the experimental. 
Table 1: List of descriptive terms and essential factors

\begin{tabular}{|c|c|c|c|c|}
\hline \multicolumn{5}{|c|}{ Description target } \\
\hline $\begin{array}{c}\text { Critical } \\
\text { coefficient }\end{array}$ & State & Color & Flavor & Overall \\
\cline { 2 - 4 } 5 & $\begin{array}{c}50 \% \\
\text { Liquid viscosity (such as } \\
\text { fruit milk, bird's nest, } \\
\text { drinking yogurt) }\end{array}$ & Pure white & $\begin{array}{c}\text { Soursop- } \\
\text { specific, } \\
\text { pleasant }\end{array}$ & $\begin{array}{c}\text { Like } \\
\text { extremely }\end{array}$ \\
\hline 4 & $\begin{array}{c}\text { Medium viscous liquid state } \\
\text { (such as milk, fruit juice) }\end{array}$ & Milky & $\begin{array}{c}\text { Light, } \\
\text { comfortable } \\
\text { taste }\end{array}$ & $\begin{array}{c}\text { Like } \\
\text { moderately }\end{array}$ \\
\hline 3 & $\begin{array}{c}\text { Liquid state (like filtered } \\
\text { water) }\end{array}$ & $\begin{array}{c}\text { White is } \\
\text { slightly } \\
\text { yellow }\end{array}$ & Odor & Accept \\
\hline 1 & $\begin{array}{c}\text { Medium consistency (like } \\
\text { yogurt) }\end{array}$ & Pale yellow & Odorless & $\begin{array}{c}\text { Neither like } \\
\text { nor dislike }\end{array}$ \\
\hline 0 & $\begin{array}{c}\text { Thickened state (like } \\
\text { concentrated fruit, puree) }\end{array}$ & Dark yellow & $\begin{array}{c}\text { Soursop, } \\
\text { uncomfortable }\end{array}$ & $\begin{array}{c}\text { Dislike } \\
\text { moderately }\end{array}$ \\
\hline condensed milk) & Vivid yellow & Strange smell & $\begin{array}{c}\text { Dislike } \\
\text { extremely }\end{array}$ \\
\hline
\end{tabular}

\section{Result and discussion}

\subsection{Effect of ultrasound, carboxymethyl cellulose concentration on $\mathrm{pH}$ value, Brix and Lab* system}

Table 2: Change of $\mathrm{pH}$, total dissolved solids after CMC homogenization process by sonication, and the Lightness/dark of nectar samples with different CMC concentrations

\begin{tabular}{|c|c|c|c|c|c|c|c|}
\hline \multicolumn{2}{|c|}{$\begin{array}{l}\text { CMC concentration } \\
(\mathrm{w} / \mathrm{v})\end{array}$} & Fresh & $0.01 \%$ & $0.05 \%$ & $0.1 \%$ & $0.15 \%$ & $0.2 \%$ \\
\hline \multirow{2}{*}{$\mathrm{pH}^{*}$} & Before & $\begin{array}{ll}4.14 & \pm \\
0.08 & \end{array}$ & $\begin{array}{ll}4.14 & \pm \\
0.14 & \end{array}$ & $\begin{array}{ll}4.21 & \pm \\
0.14 & \end{array}$ & $\begin{array}{ll}4.25 & \pm \\
0.10 & \end{array}$ & $\begin{array}{ll}4.25 & \pm \\
0.14 & \end{array}$ & $\begin{array}{ll}4.27 & \pm \\
0.15 & \end{array}$ \\
\hline & After & $\begin{array}{ll}4.13 & \pm \\
0.11 & \end{array}$ & $\begin{array}{ll}4.11 & \pm \\
0.08 & \end{array}$ & $\begin{array}{ll}4.19 & \pm \\
0.04 & \end{array}$ & $\begin{array}{ll}4.22 & \pm \\
0.10 & \end{array}$ & $\begin{array}{ll}4.23 & \pm \\
0.14 & \end{array}$ & $\begin{array}{ll}4.29 & \pm \\
0.10 & \end{array}$ \\
\hline \multirow{2}{*}{ Brix** } & Before & $\begin{array}{l}11.90 \quad \pm \\
0.14\end{array}$ & $\begin{array}{l}11.90 \quad \pm \\
0.00\end{array}$ & $\begin{array}{ll} & 11.80 \quad \pm \\
0.14 & \end{array}$ & $\begin{array}{ll}11.80 \quad \pm \\
0.28\end{array}$ & $\begin{array}{ll} & 11.95 \quad \pm \\
0.07 & \end{array}$ & $\begin{array}{l}12.00 \pm \\
0.00\end{array}$ \\
\hline & After & $\begin{array}{l}11.3 \\
0.71\end{array}$ & $\begin{array}{ll}11.6 & \pm \\
0.28 & \end{array}$ & $\begin{array}{ll}11.50 \quad \pm \\
0.28\end{array}$ & $\begin{array}{ll}11.4 & \pm \\
0.28 & \end{array}$ & $\begin{array}{ll}11.90 \quad \pm \\
0.14\end{array}$ & $\begin{array}{l}11.95 \pm \\
0.07\end{array}$ \\
\hline \multirow{4}{*}{ Color } & $\mathrm{L}^{*}$ & $\begin{array}{l}66.33 \pm \\
3.32^{\mathrm{a}}\end{array}$ & $\begin{array}{ll}64.77 & \pm \\
2.41^{\mathrm{bc}} & \end{array}$ & $\begin{array}{l}62.33 \quad \pm \\
1.96^{\text {de }}\end{array}$ & $\begin{array}{l}61.68 \quad \pm \\
1.75^{\mathrm{bcf}}\end{array}$ & $\begin{array}{l}60.30 \quad \pm \\
1.22^{\text {cf }}\end{array}$ & $\begin{array}{l}58.36 \quad \pm \\
2.12^{\mathrm{f}}\end{array}$ \\
\hline & $a^{*}$ & $\begin{array}{ll}-4.62 \quad \pm \\
0.31^{\mathrm{a}}\end{array}$ & $\begin{array}{ll}-4.13 & \pm \\
0.17^{\text {ab }} & \end{array}$ & $\begin{array}{ll}-4.23 & \pm \\
0.19^{\mathrm{ab}} & \end{array}$ & $\begin{array}{ll}-4.44 & \pm \\
0.48^{\mathrm{abc}} & \end{array}$ & $\begin{array}{ll}-3.94 & \pm \\
0.15^{\text {de }} & \end{array}$ & $\begin{array}{ll}-3.65 \quad \pm \\
0.47^{\mathrm{b}}\end{array}$ \\
\hline & $b^{*}$ & $\begin{array}{l}12.80 \quad \pm \\
0.57^{\mathrm{a}}\end{array}$ & $\begin{array}{ll}10.75 & \pm \\
0.61^{\mathrm{b}} & \end{array}$ & $\begin{array}{ll}12.33 & \pm \\
1.02^{\text {cd }} & \end{array}$ & $\begin{array}{ll}11.20 \\
1.02^{\text {be }}\end{array}$ & $\begin{array}{ll}9.99 & \pm \\
0.27^{\text {ef }} & \end{array}$ & $\begin{array}{ll}9.03 & \pm \\
0.85^{\mathrm{f}} & \end{array}$ \\
\hline & TCD & 0 & 2.62 & 4.05 & 4.92 & 6.68 & 8.87 \\
\hline
\end{tabular}


* Means there is no difference between patterns in a row. ${ }^{\mathrm{a}, \mathrm{f}}$ Result of ANOVA analysis of the difference of the two samples based on the significance level $\alpha<0.05$

As shown in Table 2, the $\mathrm{pH}$ of fruit juice products is within the acidic $\sim 4.2$ range, and most are not affected by sound waves. Similarly, the value of Brix dissolved solids before and after the process was retained the same. At the same time, they were not significantly affected amongst the CMC concentrations. In conclusion, the process of adding additives and using sinusoidal waveforms impacting the two values mentioned is negligible. However, their simultaneous influence reduces the color value of the survey sample. Color moved from light $66.33 \pm 3.32 \mathrm{a}$ to dark $64.77 \pm 2.41 \mathrm{bc}(0.01 \%)$ and $58.36 \pm 2.12 \mathrm{f}(0.2 \%)$. It can be explained that the effect of ultrasound generators causes the thermal movement of molecules. The increase in temperature destroys natural color compounds leading to, a browning reaction. In parallel, the dispersion of hydrocolloids was dense when the concentration of $\mathrm{CMC}$ is high, thickening suspended state of suspension particles, $\mathrm{L}^{*}$ and $b^{*}$ value was a decrease, $a^{*}$ move to near 0 (gradually reduce the blue). Besides, the color difference index at $0.01 \%$ was 2.62 and increased by 1.43 and 6.25 for $0.05 \%$ and $0.2 \%$, respectively. It can be affirmed that the addition of additive concentration leads to negative changes in the fluid analysis [24], [25].

\subsection{Total ascorbic acid (TAA), total phenolic content (TPC) after processing}

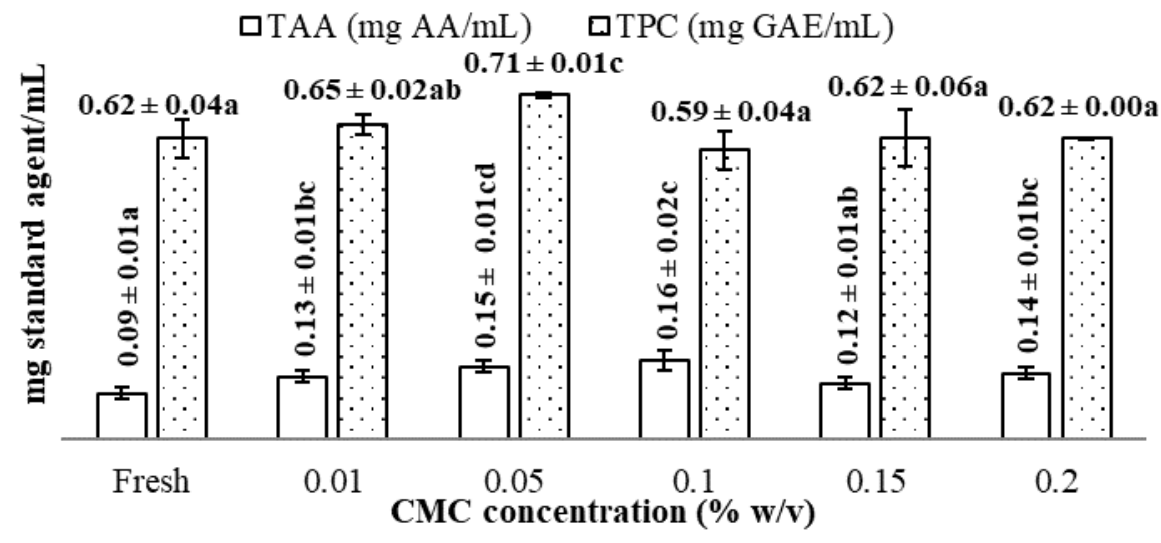

Fig. 1: Effects of CMC (\%) on TAA, TPC in cloudy Soursop juice

The TAA and TPC values were affected by the CMC concentration presented in Fig. 1. As mentioned, the value of vitamin $\mathrm{C}$ tends to increase when the concentration of CMC increases $0.09 \pm 0.01 \mathrm{a}$ (fresh) to $0.15 \pm 0.01 \mathrm{~cd}(0.05 \%)$ and $0.16 \pm 0.02 \mathrm{c}(0.1 \%)$ and stable at the remaining $\mathrm{CMC}$ levels. The results showed a positive effect on the retention of TAA at CMC concentrations of $0.01 \%$. Meanwhile, the value remained the same when increasing the volume of $\mathrm{CMC}$ up to 
2\%. Ji-Hyun Jang and Kwang-Deog Moon (2011) indicate that under the influence of ultrasound, ascorbic acid moves and disperses evenly inside the fluid, which acts as an antioxidant [26]. On the other hand, previous reports show that the ability to encapsulate ascorbic acid by CMC increases the content after treatment [27].

In addition, total phenolic content from the control sample $0.62 \pm 0.04$ increase $0.09 \mathrm{mg} \mathrm{GAE} / \mathrm{mL}$ at the addition $0.05 \% \mathrm{CMC}$. In a recent report, ultrasound was used to increase the efficiency of polyphenol extraction [28]. Application of continuous movement of sound waves into food has the effect of inhibiting enzymes that break down bioactive substances, typically PPO (polyphenol oxidase), which primarily destroys phenolic compounds [29][30], [31].

\subsection{Sensory evaluation for cloudy soursop juice}

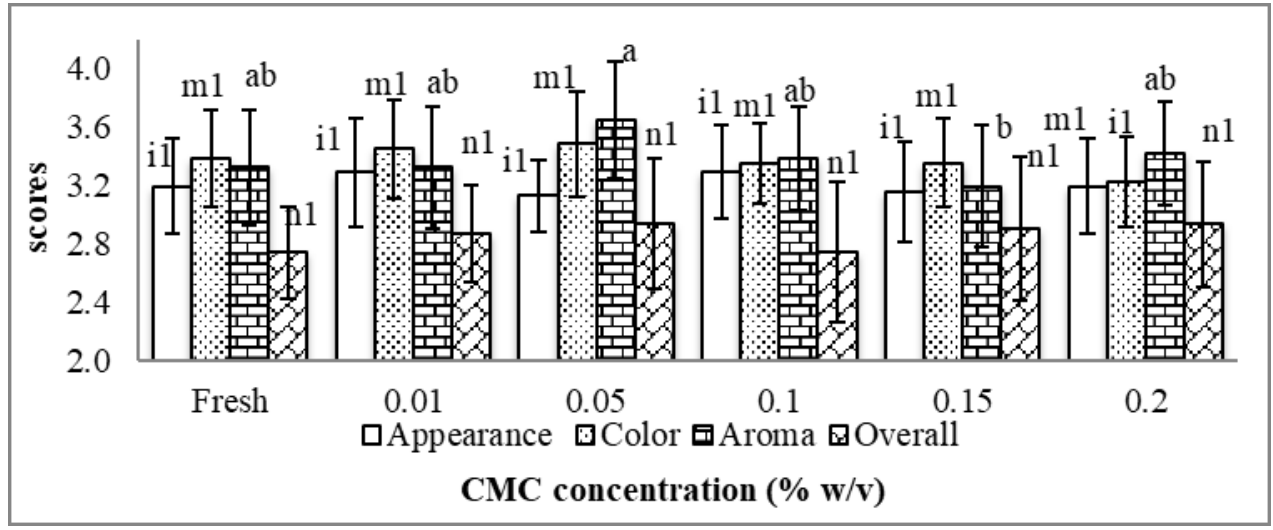

Fig. 2: The evaluation results of the sensory description of the testers are based on the given term of fruit juice appearance

The sensory results were recorded from untrained panelists Fig. 2. Cloudy Soursop juice is evaluated at the 5-point scale for color, appearance, aroma, and favorite indicators. The overall score includes the important coefficient is 13.0813.33-13.42-13.33-12.84-13.07 (fresh-0.01-0.05-0.1-0.15-0.2, respectively). Indicating that they have commercial potential in the market. The appearance (critical coefficient 50\%) of the range of 3-4 sample displays was evaluated with a Medium viscous liquid state characteristic (like milk) for samples $3.19 \pm$ $0.03 \mathrm{il}($ fresh), $3.13 \pm 0.25 \mathrm{i} 1(0.05 \%)$, and $3.19 \pm 0.33 \mathrm{ml}(0.2 \%)$. This result also indicates that the tester did not detect the difference of samples within CMC concentrations. Sensory evaluation of colors and flavors have similar value. They denote samples that have a pale white color and an easy taste. The total rating for the overall target was lower than usual from Neither like nor dislike to Accept (particularly $2.94 \pm 0.45$ at $0.05 \% \mathrm{CMC}$ ). 


\subsection{Evaluate microbiological criteria for final products}

The chosen $0.05 \%$ CMC sample has the highest antioxidant activity and sensory value from the above results. Center of analytical services reports test parameters and experimentation HCMC conform to ISO. No bacteria present Escherichia Coli (ISO 16649-3:2015) bacteria present on dish contain. In addition, Grow was carried out for Bacillus cereus (7932:2004), Clostridium perfringens (7937:2004), Coliform (4832:2006), Total yeast and mold (21527-1:2008), Total aerobic bacteria (48331$1: 2013)$ has a density lower than the allowed threshold. According to the test method, the results are less than $10 \mathrm{CFU} / \mathrm{g}$ or $1 \mathrm{CFU} / \mathrm{mL}$ when the Petri glass has no colony. The ability of ultrasound to kill microbial cells is considered to be a positive effect [32].

\section{Conclusion}

Carboxymethyl cellulose is applied not only to soft drinks but also to broader foods today. The results recorded that $\mathrm{CMC}$ did not affect the $\mathrm{pH}$ and Brix values of the sample. The homogeneous process effect CMC has sonication support on $\mathrm{L}^{*}$ coefficient, which varied from $66.33 \pm 3.32 \mathrm{a}$ to $58.36 \pm 2.12 \mathrm{f}$. At the same time, the TCD value was significantly increased with the value of 8.87 at the highest CMC concentration. Sensory evaluation results show that users accept different samples with a significant coefficient of 12-14. Notably, the additive use at a concentration of $0.05 \%$, which is considered a suitable addition, showed the most influence on the $\mathrm{TPC}, 0.71 \pm 0.01 \mathrm{mg} \mathrm{GAE} / \mathrm{mL}$. ISO testing results for microorganisms with a density of $<10 \mathrm{CFU} / \mathrm{g}$ achieved commercial standards. The limitation of this study revolves around the influence of ultrasonic waveforms and heating temperatures during additive homogenization in the fluid. Attention should be paid to the degradation of PPO enzymes under the effect of sound waves.

This research was funded by the Tien Giang Department of Science and Technology, Vietnam.

\section{References}

1. S. Alifdalino Sulaiman, Ming J. Soo, Marilyn M.L Yoon, Mohammed Farid, J. Food Eng. 147, 89-94, (2015).

2. C. Queiroz, M. Lúcia, M. Lopes, E. Fialho, and V. Lúcia, Food Rev. Int. 24, 361-375 (2008)

3. M. Toma, M. Vinatoru, L. Paniwnyk, and T. J. Mason. Sonochem. 8, 137-142 (2001).

4. J. F. Morton, Fruits warm Clim. Purdue Univ. 75-80 (1987).

5. N. P. Minh, 3, 231-236 (2015).

6. A. Umme, B. A. Asbi, Y. Sahnah, A. H. Junainah, and B. Jamilah, 58, 119-124 (1997).

7. K. hasni bte mohamad alias Ayit, 1-24, (2009).

8. J.de P. da Costa, É.M. de F.F. Rocha, and J.M.C. da Costa, Food Sci. Technol. 
34, 663-666 (2014).

9. J. G. De Melo, Antiproliferative Activity, Molecules 15, 8534-8542 (2010).

10. I.B. Gomes, R. Cristina, P. Trindade, E. Eduardo, and P. De Lemos, 771-775 (2016).

11. S. Zaidan, R. Djamil, and S. Nuraini, 7, 74-84.

12. J.L. Mclaughlin, J. Nat. Prod. 58, 830-836 (1995).

13. M. Gruschwitz, R. M. Schweiggert, and P. Esquivel, Food Res. Int. 65, 42-46 (2014).

14. S.Z. Moghadamtousi, M. Fadaeinasab, S. Nikzad, and G. Mohan, Int. J. Mol. Sci.16, 15625-15658 (2015).

15. L. Morais et al., Food Chem. 143, 398-404 (2014).

16. P. Bourke and P. Cullen, Food Sci. Technol. 21 (2010).

17. R. Cordeiro et al., LWT - Food Sci. Technol., 62, 883-889 (2015).

18. D. B. Genovese and J. E. Lozano, Food Hydrocoll. 15, 1-7 (2001).

19. S. Walker, J. Sens. Stud. 15, 285-307 (2000).

20. S. Akkarachaneeyakorn and S. Tinrat, Food Sci. Nutr. 3, 213-220, (2015).

21. T.T.Y. Nhi, N.T.V. Linh, V.T.N. Mai and T.D. Lam, Asian J. Chem., 31, 23452350, (2019).

22. B. Torres, B.K. Tiwari, A. Patras, P.J. Cullen, N. Brunton, and C.P.O. Donnell, Innov. Food Sci. Emerg. Technol., 12, 93-97 (2011).

23. Dao T.P, Nguyen D.V., Tran T.Y.N, Pham T.N., Bach L.G, Nguyen V. H, Do V. Q Nguyen V.M., Truc T.T, Food Res. (2021).

24. A. Sidor, A. Drożdżyńska, A. Brzozowska, A. Szwengiel, and A. GramzaMichałowska, Antioxidants, 9, 801, (2020)

25. T.T.Y. Nhi, N.D. Vu, N.N. Quyen, P.V. Thinh, N.T.M. Tho, T.T. Truc, IOP Conf. Ser. Mater. Sci. Eng, 991, 012013, (2020)

26. J. Jang and K. Moon, Food Chem. 124, 444-449 (2011)

27. Park et al., Biotechnol. Bioprocess Eng. 21, 110-118 (2016).

28. G.Ž. and M.Ž. Jasminka Giacometti, Foods, 7, 149 (2018).

29. M. Gallo, L. Ferrara, and D. Naviglio, Food 7, 164 (2018)

30. A. Sulaiman, M. J. Soo, M. Farid, and F. V. M. Silva, J. Food Eng. 165, 133$140(2015)$

31. T.T.Y. Nhi, P.T.N. Nhan, T.V. Thanh, D.N. Vu, D.N. Chinh, V.P. Thinh, A.T. Vy, T.L. Duc, T.T. Truc, IOP Conf. Ser. Mater. Sci. Eng. Pap., 736, 1-6, (2020).

32. G. Huang et al., Sonochemistry, 37, 144-149, 2017. 